\title{
Kurikulum Pembelajaran Bahasa Arab Di Perguruan Tinggi
}

\author{
Fatwiah Noor \\ STAI Kandangan Kalimantan Selatan \\ fatwiah.nor@gmail.com
}

\begin{abstract}
This paper present about the Arabic learning curriculum in universities in Indonesia. It discusses about curriculum concept in college from its history, that have changed from the past until now. Then, it discusses about Arabic learning viewed from learning concept and Arabic language it self. Then, the last point, the writer tried to discuss about Arabic learning curriculum in universities viewed from the aims and the learning process. This paper aims to give understanding and description about Arabic learning curriculum of universities by analyzing the curriculum that being used or facts about curriculum in universities. The writer finds that the Arabic learning curriculum in universities shows that Arabic learning depends on the learning it self in curriculum whether it as the aims of curriculum or as a tool to realize the aim of curriculum.
\end{abstract}

Keyword: curriculum, learning, Arabic language

\begin{abstract}
Abstrak
Tulisan ini menyajikan tentang kurikulum pembelajaran bahasa Arab di perguruan tinggi yang ada di Indonesia. Dalam pembahasannya disajikan tentang konsep kurikulum di perguruan tinggi mulai dari sejarah, perubahan yang terjadi dari awal sampai dengan sekarang. Kemudian juga di sajikan tentang pembelajaran bahasa arab dari segi konsep pembelajaran dan bahasa arab sendiri, kemudian di poin terakhir penulis mencoba untuk menyajikan tentang kurikulum pembelajaran bahasa arab diperguruan tinggi dengan melihat dari segi tujuan dan segi proses pembelajaran tersebut. Dari tulisan ini bertujuan untuk memberikan pemahaman dan gambaran tentang kurikulum pembelajaran bahasa Arab yang ada di Perguruan Tinggi dengan menganalisis kurikulum yang sedang berjalan atau fakta tentang kurikulum yang ada diperguruan tinggi. Adapun hasil yang penulis peroleh dari analisis kurikulum pembelajaran bahasa Arab yang ada diperguruan tinggi menunjukkan bahwa pembelajaran bahasa Arab tergantung dari posisi pembelajaran tersebut dalam kurikulum apakah sebagai tujuan dari kurikulum, ataukah sebagai alat untuk mewujudkan tujuan kurikulum tersebut.
\end{abstract}

Kata Kunci: kurikulum, pembelajaran, bahasa Arab

Arabiyatuna : Jurnal Bahasa Arab, Vol. 2, No. 1, 2018

STAIN Curup | ISSN 2580-5053 (e), 2580-5045 (p)

Available online: http://journal.staincurup.ac.id/index.php/arabiyatuna 


\section{Pendahuluan}

Pembelajaran bahasa Arab menjadi sangat menarik akhir-akhir ini untuk dibahas, hal ini dikarenakan bahasa arab bukan lagi sebatas bahasa agama tetapi sudah menjadi bahasa PBB sehingga bahasa Arab sudah dianggap sebagai bahasa komunikasi Internasional.

Dalam suatu pembelajaran tentunya kurikulum menjadi sangat penting untuk diperhatikan, dikarenakan di dalam kurikulum lah tergambar semua factor yang harus ada dalam sebuah pembelajaran. Kurikulum dan pembelajaran merupakan dua hal yang tidak terpisahkan, meskipun pada hakikatnya keduanya berada pada posisi yang berbeda, saylor menyatakan bahwa kurikulum dan pembelajaran bagaikan Qais dan Laila. Jika kita berbicara tentang Qais tentu saja kita tidak akan luput dari pembicaraan tentang Laila. Qais tidak akan berarti tanpa Laila. Demikian halnya dengan pembelajaran dan kurikulum, keduanya tidak bisa dipisahkan satu sama lainnya, pembelajaran tanpa kurikulum sebagai rencana tidak akan efektif, atau bahkan bisa keluar dari tujuan yang telah dirumuskan. Kurikulum tanpa pembelajaran pun akan sia-sia dan tidak ada manfaatnya.

Kurikulum mencakup semua elemen yang diperlukan dalam sebuah pembelajaran mulai dari tujuan, proses pembelajaran, waktu, guru, pembelajar dan lembaga itu sendiri, sehingga proses pembelajaran ada yang mengarahkan pada suatu pencapaian yang maksimal.

Dalam tulisan ini penulis sedikit menggambarkan tentang kurikulum pembelajaran bahasa arab diperguruan tinggi, mulai dari konsep kurikulum, konsep pembelajaran bahasa arab dan gambaran kurikulum pembelajaran bahasa Arab dipergururan tinggi. Dan juga bagaimana pembelajaran bahasa Arab yang ada di perguruan tinggi, apakah sesuai dengan kurikulum sebagai acuannya.

\section{Konsep Kurikulum di Indonesia}

Kurikulum memiliki makna yang beragam baik antara negara maupun antar institusi penyelenggara pendidikan. Hal ini disebabkan karena adanya cara pandang y yang berbeda terhadap kurikulum, yaitu dapat kurikulum dapat dipandang sebagai suatu rencana (plan) yang dibuat oleh seseorang atau sebagai sesuatu kejadian atau pengaruh aktual dari suatu rangkaiaan peristiwa yang terencana.

Menurut kemendiknas No. 232/U/2000, didefinisikan sebagai berikut: "Kurikulum pendidikan tinggi adalah rencana dan pengaturan mengenai isi maupun bahan kajian dan pelajaran serta cara penyampaian dan penilaiaan yang 
digunakan sebagai pedoman penyelenggaraan kegiatan belajar mengajar diperguruan tinggi.

Kurikulum adalah sebuah program yang disusun dan dilaksanakan untuk mencapai suatu tujuan pendidikan. Sehingga kurikulum dapat diartikan sebagai sebuah program yang berupa dokumen dan pelaksanaan program. Sebagai sebuah dokumen kurikulum (curriculum plan) dirupakan dalam bentuk rincian, mata kuliah, silabus, rancangan pembelajaran, sistem evaluasi keberhasilan. Sedang kurikulum sebagai sebuah pelaksanaan program adalah bentuk pembelajaran yang nyata-nyata dilakukan (actual curriculum). Akan tetapi dengan cara pandang yang luas kurikulum bisa berperan sebagai (1) manajemen pendidikan tinggi untuk menentukan arah pendidikannya, (2) filosofis yang akan mewarnai terbentuknya masyarakat dan iklim akademik, (3) Patron atau pola pembelajaran, (4) atmosfer atau iklim yang terbentuk dari hasil interaksi manajerial PT dalam mencapai tujuan pembelajaran, (5) Rujukan kualitas dari proses penjaminan mutu, serta (6) ukuran keberhasilan PT dalam menghasilkan kelulusan yang bermanfaat bagi masyarakat. Dengan ukuran bahwa kurikulum tidak hanya berarti sebagai sesuatu dokumen saja, namun mempunyai peran yang kompleks dalam proses pendidikan. ${ }^{1}$

Lebih lanjut Tresno menjelaskan bahwa tercapainya tujuan kurikulum didukung oleh Sistem pendidikan tinggi, hal ini dapat dilihat sebagai sebuah proses akan memiliki empat tahapan pokok yaitu (1) masukan (input), yaitu Dosen, mahasiswa, dsb , (2) Proses (proces) yaitu proses pembelajaran, proses penelitian dan proses manajemen, (3) Luaran (out put) yaitu lulusan, hasil penelitian dan karya IPTEK lainnya, dan (4) Hasil Ikutan ( outcome) yaitu penerimaan dan pengakuan masyarakat terhadapa luaran perguruan tinggi, kesinambungan, peningkatan mutu kehidupan bermasyarakat dan lingkungan.

Disisi lain, sistem yang baik didukung oleh beberapa unsur yang baik pula sehingga terdapat berbagai macam kategori yaitu berupa: (1) organisasi Yang sehat, (2) pengelolaan yang transparan, (3) ketersediaan rencana pembelajaran dalam bentuk dokumen kurikulum yang jelas dan sesuai dengan kebutuhan pasar kerja, (4) kemampuan dan ketrampilan sumber daya manusia dibidang akademik dan non akademik yang handal dan profesional, (5) ketersediaan sarana dan prasarana dan fasilitas belajar yang memadai, serta lingkungan akademik yang sehat, serta mengarah pada ketercapaian masyarakat akademik yang profesional. ${ }^{2}$

${ }^{1}$ Tresno Dermawan Kunaefi, dkk. Buku Panduan Pengembangan Kurikulum Berbasis Kompetensi Pendidikan Tinggi. (Jakarta: Dirjen Pendidikan Tinggi, 2008), h. 4-5

${ }^{2}$ Ibid 


\section{Kurikulum Perguruan tinggi}

Kurikulum perguruan tinggi di Indonesia tidak serta merta ada seperti sekarang ini tetapi memikili sejarah panjang yang tercatat dalam perubahanperubahan kebijakan dalam undang-undang tentang kurikulum itu sendiri. Adapun Sejarah perjalanan kurikulum perguruan tinggi di Indonesia bisa dipaparkan sebagai berikut:

1. Kurikulum yang berbasis pada pokok-pokok system pemdidikan Nasional Pancasila (UU no. 22 Tahun 1961, penetapan presiden No. 19 Tahun 1965, perpres no. 14 ahun 1965)

2. Kurikulum di atur pemenrintahan (UU. No. 2 tahun 1989, PP no. 60 tahun 1999)

3. Pergeseran paradigma ke konsep KBK, kurikulum pendidikan tinggi dikembangkan oleh perguruan tinggi yang bersangkutan dengan mengacu pada standar nasional pendidikan untuk setiap program studi (UU. No. 20 tahun 2003 pasal 8 ayat 3 dan 4, kepmendiknas no. 232/U/2000, dan perubahan kurikulum inti di kepmendiknas no 045/U/2002)

4. Kurikulum dikembangkan oleh PT sendiri (PP. no. 19 tahun 2005 pasal 17 ayat 4, PP no. 17 tahun 2010 pasal 97 ayat 2)

5. Dikembangkan berbasis kompetensi (PP no. 17 tahun 2010 pasal 97 ayat 1)

6. Minimum mengandung 5 elemen kompetensi (PP no. 17 tahun 2010 pasal 17 ayat 3$)$

7. Capaian pembelajaran sesuai dengan level KKNI ( Perpres no. 08 tahun 2012)

8. Kompetensi lulusan ditetapkan dengan mengacu pada KKNI ( UU PT No. 12 tahun 2012 pasal 29)

9. Penerapan Kerangka Kualifikasi Nasional Indonesia (Peraturan Mendikbud no 73 tahun 2013)

10. Standar Nasional Pendidikan Tinggi (Peraturan Mendikbud no 49 tahun 2014)

11. Penyelenggaraan Pendidikan jarak jauh pada PT (Peraturan Mendikbud no 109 tahun 2013)

12. Kerjasama Perguruan Tinggi (Peraturan Mendikbud no 14 tahun 2014)

Adanya perubahan kurukulum di perguruan tinggi didasari dari alasan adanya Globalisasi yang menghendaki dilakukannya perubahan pendidikan tinggi yang bersifat mendasar. Bentuk perubahan-perubahan tersebut adalah: (1) perubahan dari pandangan kehidupan masyarakat lokal ke masyarakat dunia (global), (2) perubahan dari kohesi sosial menjadi partisipasi demokratis 
(utamanya dalam pendidikan dan praktek berkewarganegaraan), dan (3) perubahan dari pertumbuhan ekonomi ke perkembangan kemanusiaan. ${ }^{3}$

Adapun Menurut Leo Agung bahwa Konsep kurikulum yang tercantum dalam Kepmendiknas No. 232/U/2000 dan No. 045/U/2000 banyak didorong oleh permasalahan Global ataupun eksternal. Menurut UNESCOhal-hal tersebut menimbulkan keadaan seperti: ${ }^{4}$

1. Persaingan di dunia Global, yang mana berakibat juga terhadap persaingan perguruan tinggi didalam negeri maupun diluar negeri, sehingga perguruan tinggi dituntut untuk menghasilkan lulusan yang dapat bersaing dalam dunia global.

2. Adanya perubahan oerintasi pendidikan tinggi yang tidak lagi hanya menghasilkan manusia cerdas berilmu akan tetapi juga mampu menerapkan keilmuaannnya dalam kehidupan dimasyarakatnya (kompeten dan relevan), yang lebih berbudaya.

3. Adanya perubahan kebutuhan didunia kerja yang terwujud dalam perubahan persyaratan dalam menerima tenaga kerja, yaitu dengan adanya persyaratan softskills yang dominan disamping hardskillnya. Sehingga kurikulum yang dikonsepkan lebih didasarkan pada rumusan kompetensi yang harus dicapai/dimiliki oleh lulusan perguruan tinggi yang sesuai atau mendekati kompetensi yang dibutuhkan oleh masyarakat pemangku kepentingan/stakeholders (competense based curiculum).

Tresno Dermawan Kunaefi ${ }^{5}$ dalam bukunya juga menyatakan bahwa perubahan ini juga didorong oleh adanya perubahan-perubahan otonomi perguruan tinggi yang dijamin dalam Undang-undang Sistem Pendidikan Nasional, yang memberi kelonggaran terhadap perguruan tinggi untuk menentuksn dan mengembangkan kurikulum sendiri. Peran DIKTI berubah yaitu hanya memfasilitasi, memberdayakan, dan mendorong perguruan tinggi untuk mencapai tujuannya, jadi tidak lagi berperan sebagi penentu atau regulator seperti masa-masa sebelumnya. Secara konseptual dipisahkan antar pengembangan kelembagaan dan pengembangan kurikulum/isi pendidikannya, sehingga perguruan tinggi lebih bisa mengembangkan dirinya sehingga sesuai dengan kemampuan dan tujuan yang dicapai. Sangat mungkin perubahan

3 Direktorat Akademik Direktorat Pendidikan Tinggi, Buku Panduan Pengembangan Kurikulum Berbasis Kompetensi Pendidikan Tinggi (Sebuah Alternatif Penyusunan Kurikulum) (Jakarta: 2008), 1

${ }^{4}$ Leo Agung. 2010. Tinjauan Kurikulum Pendidikan Sejarah Program Pasca Sarjana UNS. Majalah ilmiah IPS. Vol.11.No. 2 September 2010

5 Tresno Dermawan Kunaefi, dkk. Buku Panduan Pengembangan Kurikulum Berbasis Kompetensi Pendidikan Tinggi.( Jakarta: Dirjen Pendidikan Tinggi, 2008), h. 7 
kurikulum disebabkan juga oleh adanya perubahan rencana strategis perguruan tinggi yang termuat dalam visi dan misi.

Perubahan yang sangat pesat dan cepat disemua sektor kehidupan khususnya dunia kerja, mendorong perguruan tinggi perlu membekali lulusannya dengan kemampuan adaptasi dan kreativitas agar dapat mengikuti perubahan dan perkembangan yang cepat tersebut. Alasan inilah yang mendorong perguruan tinggi di Indonesia untuk melakukan perubahan paradigma dalam penyusunan kurikulumnya. Tidak hanya memfokuskan pada isi yang harus dipelajari, akan tetapi akan menitik beratkan pada kemampuan apa yang harus dimiliki lulusannya sehingga dapat menghadapi kehidupan masa depan dengan lebih baik serta dapat meningkatkan kualitas hidupnya. Konsep kurikulum yang didasarkan pada empat pilar pendidikan dari UNESCO, merupakan pengubahan orientasi kurikulum secara mendasar. Yaitu dari sebelumnya yang berfokus pada kemampuan manusia di masyarakatnya, lebih luas lagi yaitu pada kebudayaannya. ${ }^{6}$

Bentuk perubahan menurut Leo Agung diambil dari Pembahasan konsep kurikulum pendidikan tinggi yang dituangkan dalam kemendiknas No. 232/2000 dan No. 045/2000, mengacu kepada konsep pendidikan tinggi abad XXI UNESCO (1998), dari situ terdapat perubahan mendasar diantaranya ${ }^{7}$ :

1. Out Put hasil pendidikan yang semula berupa kemampuan minimal penguasaan pengetahuan ketrampilan, dan sikap sesuai dengan sasaran kurikulum program studi, diganti dengan kopetensi seseorang untuk dapat melakukakn seperangkat tindakan cerdas, penuh tanggung jawab sebagai syarat untuk dianggap mampu oleh masyarakat dalam melaksanakan tugastugas dalam bidang pekerjaan tertentu. Out put dalam hasil pendidikan tinggi ini semula penilaiannnya dilakukan oleh penyelenggara pendidikan tinggi sendiri, dalam konsep baru dalam penilaiaan selain oleh perguruan tinggi juga dilakukakn oleh masyarakat pemangku kepentingan.

2. Kurikulum program studi yang semula disusun dan ditetapkan oleh pemerintahan lewat sebuah konsersium (kurikulum nasional), diubah dimana kurikulum inti disusun oleh pergurua tinggi bersama-sama. Dengan pemangku kepentingan dan kalangan profesi, dan ditetapkan oleh perguruan tinggi yang bersangkutan.

3. Berdasarkan kemendikbud N0. 056/1994 kompenen kurikulum tersusun atas kurikulum nasional ( Kurnas) dan kurikulum Lokal (Kurlok) disusun dengan tujuan untuk menguasai isi ilmu pengetahuan dan penerapannya

\footnotetext{
${ }^{6}$ Sutrisno dan suyadi, Desain kurikulum Perguruan Tinggi mengacu KKNI, (Bandung: Remaja Rosdakarya, 2016) h.70-71

${ }^{7}$ Leo Agung. 2010. Tinjauan Kurikulum Pendidikan Sejarah Program Pasca Sarjana UNS. Majalah ilmiah IPS. Vol.11.No. 2 September 2010
} 
(conten Based), sedangkan dalam Kemendiknas No. 232/U/2000 kurikulum terdiri atas kurikulum inti dan kurikulum institusional. Kurikulum inti merupakan penciri dari kopetensi utama, ditetapkan oleh kalangan perguruan tinggi bersama masyarakat profesi dan pengguna lulusan. Sedangkan kompetensi pendukung dan kopetensi lain yang bersifat khusus dengan kompetensi utama suatu program studi ditetapkan oleh institusi pennyelenggara program studi (Kemendiknas No.045/U/2000).

4. Dalam Kemendiknas No. 232/U/2000, kurikulum terdiri dari kelompokkelompok Mata Kuliah Pengembangan Kepribadian (MPK), Mata Kuliah Keilmuan dan Ketrampilan (MKK), Mata Kuliah Keahlian Berkarya (MKB), Mata Kuliah Perilaku Berkarya (MPB), dan Mata Kuliah Berkehidupan Bersama (MBB). Akan tetapi dikatan dalam Kemendiknas N0. 045/U/2002, pengelompokan mata kuliah tersebut diluruskan agar maknanya agar lebih luas dan tepat melalui pengelompokan berdasarkan elemen kompetensinya, yaitu berupa: (a) landasan kepribadian, ( b) penguasaan ilmu dan ketrampilan, (c) kemampuan berkarya, (d) sikap dan perilaku dalam berkarya menurut tingkat keahlian berdasarkan ilmu dan ketrampilan yang dikuasai, (e) pemahaman kaidah kehidupan bermasyarakat sesuai dengan pilihan keahlian dalam berkarya.

5. Perubahan kurikulum juga berarti perubahan pembelajaran, sehingga denga konsep pembelajaran yang dilakukan di pendidikan tinggi tidak hanya sekedar suatu proses transfer of knowledge, namun benar-benar merupakan suatu proses pembekalan berupa method of inquiry seseorang yang berkopenten dalam berkarya di masyarakat. Dengan demikian secara jelas akan tampak bahwa perubahan kurikulum dari kurikulum berbasis penguasaan ilmu penengetahuan dan ketrampilan (KBI) sesuai dengan Kemendikbud No. 056/U/1994, ke KBK menurut Kemendiknas No. 2323/U/2000, mempunyai harapan keunggulan yaitu berupa: "luaran hasil pendidikan (outcomes) yang diharapkan sesuai dengan sociel needs, industrial/business needs, dan profesional needs, dengan pengertian bahwa outcomes merupakan kemampuan mengintegrasikan intelectual skill, knowledge dan afektif dalam sebuah perilaku secara utuh."

Masih Leo Agung dalam tulisannya Langkah-langkah yang harus dilakukan dalam menyususn kurikulum adalah dengan melakukan analisis SWOT dan Tracer Study serta Labor Maket Signal. Hal ini jarang dipertimbangkan apakah kelulusannya nanti relevan dengan kebutuhan masyarakat pemangku kepentingsn (stakeholders) atau tiudak.

Adapun alternatif penyusunan kurikulum berbasis kompetensi dapat dimulai dengan langkah langkah berikut : 
1. Penyusunan profil lulusan, yaitu berupas peran dan fungsi yang diharapkan dapat dijalankan oleh lulusan nantinya dimasyarakat.

2. Penetapan kompetensi berdasarkan profil lulusan yang telah dirancangkan.

3. Penentuan bahan kajian yang terkait dengan bidang IPTEK program studi.

4. Penetapan kedalam dan keluasan kajian (sks) yang dilakukan dengan menganalisis hubungan antara kompetensi dan bahan kajian yang diperlukan.

5. Merangkai berbagai macam kajian tersebut ke dalam mata kuliah.

6. Menyususn struktur kurikulum dengan cara mendistribusikan mata kuliah tersebut dalam semester.

7. Mengembangkan rancanagan pembelajaran secara simultan

8. Memilih metode pembelajaran yang tepast untuk mencapai kompetensi

\section{KKNI sebagai acuan kurikulum di Indonesia}

Kerangka Kualifikasi Nasional Indonesia atau KKNI adalah suatu rujukan nasional untuk meningkatkan mutu dan daya saing bangsa Indonesia, sebagaimana disebutkan dalam Perpres nomor 8 tahun 2012, bahwa KKNI merupakan kerangka penjenjangan kualifikasi kompetensi yang dapat menyandingkan, menyetarakan dan mengintegrasikan antara bidang pendidikan dan bidang pelatihan kerja serta pengalaman kerja dalam rangka pemberian pengakuan kompetensi kerja sesuain dengan struktur pekerjaan dibeberapa sektor. ${ }^{8}$

KKNI yang secara resmi dimiliki Indonesia sejak tahun lalu lewat Peraturan Pemerintah Nomor 8 Tahun 2012 tentang KKNI saat ini mulai gencar disosialisasikan, termasuk kepada kalangan perguruan tinggi. Implementasi KKNI ditargetkan tahun 2016, yakni penyetaraan antara kualifikasi lulusan dengan kualifikasi KKNI, pengalaman pembelajaran lampau (PPL), pendidikan multi entry dan multi exit, dan pendidikan sistem terbuka.

Secara umum istilah KKNI masih banyak disalahfahami sebagai sebuah kurikulum yang harus dipakai dan diterapkan khususnya di jenjang perguruan Tinggi, hal ini bisa kita lihat dari contoh sederhana, banyak top leader perguruan tinggi yang masih keliru dalam penyebutan KKNI, sebagai “ Kerangka Kurikulum Nasional Indonesia, Kualifikasi kurikulum Nasional Indonesia, Kurikulum Kualifikasi Nasional Indonesia," dan sebagainya.

Kesalahan umum yang tejadi di atas adalah bahwa KKNI dipahami hanya sebatas kurikulum. Akibatnya mayoritas perguruan tinggi di Indonesia saat ini sedang "demam kurikuluk KKNI". Padahal, KKNI bukan kurikulum.

8 Depdiknas, Buku Pedoman Kerangka Kualifikasi Nasional Indonesia, Jakarta: direktorat Jenderal Perguruan Tinggi, 2010), h. i 
Bahkan secara lebih tegas bahwa KKNI tidak hanya membidangi pendidikan tinggi, melainkan berbagai sector, seperti tenaga kerja, birokrasi pemerintah, pelatihan, industry, dunia usaha dan bidang lainnya sebagaimana tergambar dalam Perpres nomor 8 tahun 2012. Dengan demikian, KKNI bidang pendidikan tinggi hanya salah satu sector dari KKNI secara umum, adapun kurikulum yang harus mengacu pada KKNI hanya bagian kecil dari mata rantai panjang KKNI bidang pendidikan tinggi.

Menurut Illa dalam harian kompas bahwa, KKNI yang disusun oleh Kementerian Tenga Kerja Transmigrasi dan Kemendikbud ini, menjadi acauan untuk sumber daya manusia Indonesia dan asing yang bekerja di Indonesia. "Selama ini, kita di luar negeri selalu ditanya kerangka kualifikasi nasional. Jadi, KKNI adalah jati diri bangsa sebagai penilaian kesetaraan da pengakuan kualifikasi, baik untuk SDM Indonesia maupun asing," kata Illa. ${ }^{10}$ Jadi dalam kesempatan itu beliau berpendapata bahwa KKNI adalah sarana untuk memfasilitasi belajar sepanjang hayat dan penyetaraan, dalam ungkapannya, "KKNI ini untuk memfasilitasi belajar sepanjang hayat dan penyetaraan. KKNI ini akan menjadi rujukan dalam kurikulum dan penjaminan mutu pendidikan. Untuk itu, capaian belajar lulusan atau learning outcomes dari proses pendidikan harus mengacu pada KKNI," kata Direktur Pembelajaran dan Kemahasiswaan, Direktorat Jenderal Pendidikan Tinggi, Kementerian Pendidikan dan Kebudayaan, Illa Saillah, Selasa (2/4/2013) di Jakarta. ${ }^{11}$

Dengan adanya Kerangka Kualifikasi Nasional Indonesia (KKNI) dari level 1-9 menjadi acuan untuk pembangunan sumber daya manusia dan Tenaga Kerja Indonesia. Pengakuan kualifikasi tidak hanya mengacu pada pendidikan formal, tetapi juga pelatihan yang didapat di luar pendidikan formal, pembelajaran mandiri, dan pengalaman kerja. Sehingga pada nantinya diperlukan adanya sertifikasi kompetensi sebagai bukti kompetensi tersebut.

Sedangkan Prinsip dasar yang dikembangkan dalam KKNI adalah unjuk kerja seseorang dalam aspek-aspek keilmuan, keahlian dan keterampilan sesuai dengan capaian pembelajaran (learning outcomes) yang diperoleh melalui proses pendidikan, pelatihan atau pengalaman yang telah dilampauinya, yang setara dengan deskriptor kualifikasi untuk suatu jenjang tertentu. Terkait dengan proses pendidikan, capaian pembelajaran merupakan hasil akhir atau akumulasi proses peningkatan keilmuan, keahlian dan keterampilan seseorang yang

\footnotetext{
${ }^{9}$ Sutrisno dan suyadi, Desain kurikulum Perguruan Tinggi mengacu KKNI, (Bandung: Remaja Rosdakarya, 2016) h.v-iv Pendidikan

${ }^{10}$ http://edukasi.kompas.com/read/2013/04/02/1917141/KKNI.Jadi.Acuan. Pendidikan

${ }^{11}$ http://edukasi.kompas.com/read/2013/04/02/1917141/KKNI.Jadi.Acuan.
} 
diperoleh melalui pendidikan formal, informal atau nonformal. Dalam arti yang lebih luas, capaian pembelajaran juga diartikan sebagai hasil akhir dari suatu proses peningkatan kompetensi atau karir seseorang selama bekerja. Pinsip dasar ini sesuai dengan pendekatan yang dilakukan oleh negara-negara lain dalam mengembangkan kerangka kualifikasi masing-masing.

Sangat penting untuk menyatakan juga bahwa KKNI merupakan perwujudan mutu dan jati diri BangsaIndonesia terkait dengan sistem pendidikan nasional dan pelatihan yang dimiliki negara Indonesia. Maknanya adalah, dengan KKNI ini memungkinkan hasil pendidikan, khususnya pendidikan tinggi, diperlengkapi dengan perangkat ukur yang memudahkan dalam melakukan penyepadanan dan penyejajaran dengan hasil pendidikan bangsa lain di dunia. KKNI juga menjadi alat yang dapat menyaring, hanya orang atau SDM yang berkualifikasi yang dapat masuk ke Indonesia.

\section{Pembelajaran Bahasa Arab}

\section{a. Konsep pembelajaran}

Pembelajaran menurut beberapa ahli diantaranya Gagne mendefinisikan istilah pembelajaran sebagai "a set of events embedded in purposeful activities that facilitate learning" ${ }^{2}$. Pembelajaran adalah serangkaian aktivitas yang sengaja diciptakan dengan maksud untuk memudahkan terjadinya proses belajar.

Definisi lain tentang pembelajaran dikemukakan oleh Patricia L. Smith dan Tillman J. Ragan (1993) yang mengemukakan bahwa pembelajaran adalah pengembangan dan penyampaian informasi dan kegiatan yang diciptakan untuk memfasilitasi pencapaian tujuan yang spesifik. ${ }^{13}$

Yusufhadi Miarso (2005. P.144) memaknai istilah pembelajaran sebagai aktifitas atau kegiatan yang berfokus pada kondisi dan kepentingan pembelajaran (learner centered). Istilah pembelajarn digunakan untuk menggantikan istilah "pembelajaran" yang lebih bersifat sebagai aktivitas yang berfokus pada guru (teacher centered). Oleh karenanya, kegiatan pembelajaran perlu dibedakan dari kegiatan pembelajaran. ${ }^{14}$

Lebih lanjut, Miarso menyatakan bahwa pembelajaran merupakan istilah yang diartikan sebagai penyajian bahan ajaran yang dilakukan oleh seseorang

\footnotetext{
${ }^{12}$ Robert M. Gagne, Principle Of Instructional Design, (New York: Wadsworth Publishing Co, 2005), h.1

13 Patricia L. Smith dan Ragan T.L, Instructional Design. Upper Saddle River, (New York: Merril Prentice Hall Inc; 2003), h.12 h.144

${ }^{14}$ Y. Miarso, Menyemai Benih Teknologi Pendidikan, (Jakarta: Penerbit Kencana, 2005),
} 
pengajar. Berbeda dengan istilah pembelajaran, kegiatan pembelajaran tidak harus diberikan oleh pengajar karena kegiatan ini dapat dilakukan oleh perancang dan pengembang sumber belajar, misalnya seorang teknologiwan pembelajaran atau suatu tim yang terdiri dari ahli media dan ahli materi ajaran tertentu. Istilah pembelajaran telah digunakan secara luas bahkan telah dikuatkan dalam perundang-undangan, yaitu dalam Undang-undang Sistem Pendidikan Nasional Nomor 20 Tahun 2003.

Sejalan dengan pendangan diatas, Gagne dan kawan-kawan dalam Richey secara rinci mengemukakan pandangan yang membedakan antara pembelajaran dengan pembelajaran sebagai berikut.

“. . . istilah pembelajaran mengandung makna yang lebih luas dari pada istilah pembelajaran. Pembelajaran hanya merupakan upaya transfer of knowledge semata dari guru kepada siswa, sedangkan pembelajaran memiliki makna yang lebih luas, yaitu kegiatan yang dimulai dari mendesain, mengembangkan, mengimplementasikan, dan mengevaluasi kegiatan yang dapat menciptakan terjadinya proses belajar." ${ }^{15}$

Pembelajaran adalah proses yang sengaja dirancang untuk menciptakan terjadinya aktivitas belajar dalam diri individu. Dengan kata lain, pembelajaran merupakan sesuatu hal yang bersifat eksternal dan sengaja dirancang untuk mendukung terjadinya proses belajar internal dalam diri individu.

Walter Dick dan Lou Carey mengidentifikasi pembelajaran sebagai rangkaian peristiwa atau kegiatan yang disampaikan secara terstruktur dan terencana dengan menggunakan sebuah atau beberapa jenis media. Proses pembelajaran mempunyai tujuan agar siswa dapat mencapai kompetensi seperti yang diharapkan. Untuk mencapai tujuan tersebut proses pembelajaran perlu dirancang secara sistematik dan sistemik. ${ }^{16}$

Dari uraian itu, maka tampak jelas bahwa istilah "pembelajaran" (instruction) itu menunjukkan pada usaha siswa mempelajari bahan pelajaran sebagai akibat perlakuan guru. Di sini jelas, proses pembelajaran yang dilakukan siswa tidak mungkin terjadi tanpa perlakuan guru. Yang membedakannya hanya terletak pada peranannya saja.

Dalam istilah "pembelajaran" yang lebih dipengaruhi oleh perkembangan hasil-hasil teknologi yang dapat dimanfaatkan untuk kebutuhan belajar, siswa diposisikan sebagai subjek belajar yang memegang peranan yang

\footnotetext{
${ }^{15}$ Robert M. Gagne, Principle Of Instructional Design, (New York: Wadsworth Publishing Co, 2005), h.1

16 Walter Dick dkk, The Systematic Design Of Instruction, (New York: Pearson, 2005), h.205
} 
utama, sehingga dalam setting proses belajar mengajar siswa dituntut beraktivitas secara penuh, bahkan secara individual mempelajari bahan pelajaran. Dengan demikian, kalau dalam istilah "mengajar (pembelajaran)" atau "teaching" menempatkan guru sebagai "pemeran utama" memberikan informasi, maka dalam "instruction" guru lebih banyak berperan sebagai fasilitator, me-manage berbagai sumber dan fasilitas untuk dipelajari siswa. Hal ini mengisyaratkan bahwa dalam proses belajar mengajar siswa harus dijadikan sebagai pusat dari kegiatan. Hal ini dimaksudkan untuk membentuk watak, peradaban, dan meningkatkan mutu ke-hidupan peserta didik. Pembelajaran perlu memberdayakan semua potensi peserta didik untuk menguasai kompetensi yang diharapkan. Pemberdayaan diarahkan untuk mendorong pencapaian kompetensi dan perilaku khusus supaya setiap individu mampu menjadi pembelajar sepanjang hayat dan mewujudkan masyarakat belajar.

\section{b. Bahasa Arab dan pembelajarannya}

Bahasa adalah salah satu hal yang sangat penting dalam sebuah kehidupan manusia. Sebab dengan bahasa itulah manusia bisa berkomunukasi dan menyampaikan semua gagasan dan isi pikirannya, memenuhi semua kebutuhan hidupnya dan mewarnai kehidupannya. Adapun makna bahasa beragam, tergantung pada perspektif yang memberi makna terhadap bahasa tersebut dan motif yang ingin dicapainya.

Dalam buku Pedoman Pembelajaran bahasa Arab pada Perguruan Tinggi Agama"/IAIN, diungkapkan bahwa sebenarnya bahasa adalah sistem lmbanglambang berupa bunyi yang digunakan oleh segolongan masyarakat tertentu untuk berkomunikasi dan berinteraksi. ${ }^{17}$

Sedangkan, bahasa menurut Kamus al-Wasith adalah suatu lambang suara yang digunakan oleh kaum untuk mengungkapkan maksud tujuan mereka (pikiran, perasaan yang terlintas di hati mereka) ${ }^{18}$. Ungkapan kamus ini tampaknya senada dengan pendapat Syekh Ghalayain yang mengatakan bahwa bahasa adalah suatu kumpulan lafal yang dipakai oleh suatu kaum untuk mengungkapkan tujuan-tujuan (pikiran dan perasaan) mereka ${ }^{19}$. Sedangkan, menurut Kamus Besar bahasa Indonesia, bahasa adalah (1) sistem lambang bunyi berartikulasi (yang dihasilkan alat-alat ucap) yang bersifat sewenang-wenang dan konversional yang dipakai sebagai alat komunikasi untuk melahirkan perasaan

17 A.Akrom Malibary dkk, Pedoman Pembelajaran Babasa Arab Pada Perguruan Tinggi Agama/ I.A.I.N, (Jakarta: Depag R.I, 1976), h.19 h. 831

${ }^{18}$ Ibrahim Anis dkk, Al-Mu'jam al-Wasith, (Tanpa kota: Tanpa Penerbit, tanpa Tahun),

19 Musthafa Al-Ghalayaini, Jami' ad-Durus al-Arabiyabjilid 1, (Beirut: Dar al-Kutub alIslamyah, 2005), h. 7 
dan pikiran; (2) perkataan-perkataan yang dipakai oleh suatu bangsa (suku bangsa, negara, daerah); dan (3) perkataan yang baik, sopan-santun, tingkah laku yang baik. ${ }^{20}$

Selain itu, Kridalaksana, sebagaimana yang dikutip oleh Akhmad Muzakki, mendefinisikan bahwa sebagai sistem lambang bunyi yang arbiter, yang digunakan oleh para anggota kelompok sosial untuk bekerja sama, berkomunikasi, dan mengidentifikasi diri. Akhmad Muzakki juga mengutip pendapat beberapa pakar bahasa yang lain, di antaranya adalah Ibnu Jinni. Ibnu Jinni menyatakan bahwa bahasa adalah bunyi yang digunakan oleh setiap bangsa atau masyarakat untuk mengemukakan ide. Ia juga mengutip pendapat Al-Khuli yang menyatakan bahwa bahasa adalah sistem lambang bunyi yang arbiter, yang digunakan untuk saling bertukar pikiran dan perasaan antaranggota kelompok masyarakat bahasa. ${ }^{21}$

Dalam bahasa Arab sendiri, bahasa di sebut dengan kata “لغة" itu berawal dari bentuk "غا", yang artinya berbicara. Dari sini dapat ditarik kesimpulan bahwa sifat umumnya adalah sesuatu yang berwujud bunyi yang keluar dari mulut dengan sedemikian rupa hingga bunyi itu mengandung atau mempunyai arti tertentu.

Sedangkan bahasa Arab secara khusus Menurut Al-Ghalayain adalah kalimat-kalimat yan dipergunakan oleh orang Arab untuk mengungkapkan tujuan-tujuan (pikiran dan perasaan) mereka. ${ }^{22}$

Menurut Ummi Mahmudah dalam bukunya menjelaskan bahwa Bahasa Arab termasuk rumpun semit atau semitik, sebagaimana telah disebutkan sebelumnya. Bahasa semit adalah bahasa yang dipakai oleh orang-orang atau bangsa yang tinggal di sekitar Sungai Tigris dan Eufrat, daratan Syiria dan Jazirah Arabia (Timur Tengah), seperti bahasa Finisia, Asyiria, Ibrani, Arabia, Suryania, dan Babilonia. Dari sekian banyak bahasa tersebut, yang dapat bertahan sampai sekarang adalah Ibrani. Sebenarnya, bahasa Arab muncul sejak abad sebelum Islam. Sebab, bukti peninggalan bahasa Arab baru dapat dicatat hanya mulai sejak dua abad sebelum Islam, sehingga pencatatan bahasa Arab baru bisa dimulai saat ini. ${ }^{23}$

${ }^{20}$ Departemen Pendidikan dan Kebudayaan, Kamus Besar Bahasa Indonesia, Jakarta: Balai Pustaka,1989), h.66

${ }^{21}$ Akhmad Muzakki, Stilistika al-Qur'an; Gaya Babasa al-Qur'an dalam Konteks Komunikasi, (Malang: UIN Press,2009), h.89

${ }^{22}$ Musthafa al-Ghalayaini, Op. Cit., h.7

${ }^{23}$ Umi Machmudah dan Abdul Wahab Rosyidi, Active Learning dalam Pembalajaran Bahasa Arab, (Malang: UIN Press, 2008), h.7 
Seperti yang sudah dijelaskan di atas, sebuah Pembelajaran merupakan upaya membelajarkan siswa. Kegiatan pengupayaan ini akan mengakibatkan siswa dapat mempelajari sesuatu dengan cara efektif dan efisien. Upaya-upaya yang dilakukan dapat berupa analisis tujuan dan karakteristik studi dan siswa, analisis sumber belajar, menetapkan strategi pengorganisasian, isi pembelajaran, menetapkan strategi penyampaian pembelajaran, menetapkan strategi pengelolaan pembelajaran, dan menetapkan prosedur pengukuran hasil pembelajaran. Oleh karena itu, setiap pengajar harus memiliki keterampilan dalam memilih strategi pembelajaran untuk setiap jenis kegiatan pembelajaran. Dengan demikian, dengan memilih strategi pembelajaran yang tepat dalam setiap jenis kegiatan pembelajaran, diharapkan pencapaian tujuan belajar dapat terpenuhi. Dalam hal ini peran pengajar lebih erat kaitannya dengan keberhasilan pembelajar, terutama berkenaan dengan kemampuan pengajar dalam menetapkan strategi pembelajaran.

Pembelajaran yang baik memerlukan suatu proses perencanaan yang disusun secara matang dan sesuai dengan standar proses pendidikan kesetaraan yang meliputi: Perencanaan Proses Pembelajaran, Pelaksanaan Pembelajaran, Penilaian Proses dan Hasil Pembelajaran,dan Pengawasan Proses Pembelajaran. Standar Proses Pendidikan Kesetaraan ini kemudian dirumuskan dalam Kurikulum Pendidikan Kesetaraan.

Belajar bahasa pada hakikatnya adalah belajar komunikasi. Oleh karena itu, pembelajaran bahasa adalah upaya membelajarkan siswa bagaimana cara berkomunikasi dalam hal ini dikhususkan untuk pembelajaran berkomunikasi dengan bahasa arab. pembelajaran diarahkan untuk meningkatkan kemampuan pembelajar dalam berkomunikasi bahasa arab, baik lisan maupun tulis. Hal ini relevan dengan kurikulum 2004 bahwa kompetensi pembelajar bahasa diarahkan ke dalam empat subaspek, yaitu keterampilan menyimak (mabärat al-istimāa), keterampilan berbicara (mahärat al-kaläm), keterampilan membaca (mahärat alqiräab), dan keterampilan menulis (mahärat al-kitäbah). Menyimak dan berbicara adalah dua keterampilan yang berkaitan dengan penggunaan bahasa Arab secara lisan, sedangkan membaca dan menulis adalah dua keterampilan yang berkaitan dengan penggunaan bahasa Arab secara tulisan.

Selain keempat keterampilan di atas, ada aspek lain yang tidak kalah pentingnya dan ikut mempengaruhi ketercapaian tujuan pembelajaran bahasa Arab secara komprehensif. Aspek tersebut adalah unsur-unsur bahasa (al-anāshir 
al-lughawiyyah), yaitu fonologi (ashwat), morfologi (sharaf), sintaksis/Kalimat (nahwu), semantik (dalālah), dan kosakata (mufradāt) ${ }^{24}$.

\section{c. Kurikulum pembelajaran bahasa Arab di Indonesia}

Bahasa Arab sudah diajarkan di Indonesia sejak Islam tersebar ke bumi Nusantara ini, yaitu kira-kira abad ke-13 M. Dahulu, pembelajaran bahasa Arab hanya sekedar untuk mendalami dan memahamiajaran Islam yang termaktub dalam kitab suci al-Qur'an dan hadits, yang keduanya ditulis dalam bahasa Arab, oleh karena itu memahami dan mempelajari bahasa Arab adalah sebuah keniscayaan.

Tampaknya, tujuan pembelajaran bahasa Arab pada zaman sekarang sudah banyak mengalami perkembangan. Hal ini terbukti dengan pembelajaran bahasa Arab di Indonesia sudah dimulai dari pendidikan anak usia dini atau TK sampai perguruan tinggi. Adanya pembelajaran bahasa Arab disekolah, perguruan tinggi, dan lembaga-lembaga pendidikan Islam lainnya menunjukkan keseriusan untuk memajukan sistem dan mutunya.

Dalam buku yang berjudul Pendekatan Metode dan Teknik Pembelajaran Bahasa Arab, Fuad Effendy dan Fachruddin Djalal mengemukakan bahwa tujuan pembelajaran bahasa Arab dibedakan menjadi tiga, yakni:

\section{Tujuan Strategis}

Tim penyusun buku Pedoman Bahasa Arab Departemen Agama merumuskan tujuan strategis pembelajaran bahasa Arab di Indonesia yakni:

1. Untuk menunjang pembinaan kebudayaan nasional. Tujuan ini sehubungan dengan perananan bahasa Arab yang cukup berarti dalam kebudayaan nasional.

2. Untuk menunjang pembangunan nasional. Hal ini sehubungan dengan tujuan pembangunan nasional yang tidak saja mementingkan aspek materiil tapi juga aspek spiritual, dan bahasa Arab adalah bahasa agama islam yang dipeluk oleh sebagian besar rakyat Indonesia.

\section{Tujuan Umum}

Tujuan umum adalah tujuan pembelajaran bahasa Arab yang tercantum dalam kurikulum.Tujuan umum ini antara lain:

${ }^{24}$ Fadhil Fathy Muhammad Waly. 1998.Tadris al-Lughah al-Arabiyyah Fy al-Marbalah alIbtida'iyyah: Thuruqubu, Asalibubu, Qadhayabu.( Ha'il: Dar al-Andalus Li al-Nasyr wa alTauzi',1998). h. 145 
1. Pembelajaran bahasa Arab sebagai tujuan, dimaksudkan untuk membina ahli bahasa Arab, yang meliputi bidang ilmu bahasa (linguistik), bidang pembelajaran bahasa dan bidang sastra.

2. Pembelajaran bahasa Arab sebagai alat, dimaksudkan untuk memberikan kepada siswa kemahiran dalam bahasa Arab dalam aspek tertentu sebagai alat untuk keperluan tertentu pula. Misalnya, sebagai alat untuk komunikasi dalam pergaulan sehari-hari, sebagai alat untuk memahami buku-buku berbahasa Arab, sebagai alat pembantu keahlian lain (supplementary), sebagai alat pembantu tehnik (vocational).

\section{Tujuan Khusus(instruksional)}

Yang dimaksud tujuan khusus ialah tujuan untuk masing-masing langkah (step) pada setiap pokok bahasan. Tujuan khusus ini hendaknya cukup operasional dan spesifik sehingga dapat dijadikan dasar untuk menetapkan jenis tes yang akan digunakan untuk mengetahui sejauh mana tujuan-tujuan yang diinginkan anak dari aspek fisik bahasa dapat tercapai.

Adapun tujuan akhir dari pembelajaran bahasa Arab ialah agar siswa terampil berbahasa: trampil menyimak, berbicara, membaca dan menulis. ${ }^{25}$

Selain pengklasifikasian diatas, tujuan pembelajaran bahasa Arab secara umum dibagi menjadi dua yaitu:

\section{Tujuan Pembelajaran Bahasa Arab Secara Umum}

Tujuan umum adalah tujuan pembelajaran bahasa Arab yang tercantum dalam kurikulum, baik itu disekolah, perguruan tinggi maupun lembaga-lembaga pendidikan Islam lainnya. Tujuan umum ini antara lain:

Menurut Abu Bakar tujuan umum ialah tujuan dari pelajaran itu sendiri dan yang bertalian dengan bahan pelajaran tersebut ${ }^{26}$. Tujuan umum sulit dicapai tanpa dijabarkan secara operasional dan spesifik. Adapun tujuan umum pembelajaran bahasa Arab adalah sebagai berikut: ${ }^{27}$

1. Tujuan Religius

Yaitu belajar bahasa Arab dengan tujuan memahami dengan tujuan memahami dan mengajarkan ajaran Agama Islam yang termaktub dalam al1990), h.2.

${ }^{25}$ Henry Guntur Tarigan, Pembelajaran Kompetensi Bahasa (Bandung: Angkasa Bandung.

${ }^{26} \mathrm{Abu}$ Bakar Muhammad, MetodeKhususPembelajaranBahasa Arab (Surabaya: Usaha Nasional, 1981) h.5.

27 Acep Hermawan, Metodologi Pembelajaran Bahasa Arab, (Bandung: Remaja Rosdakarya,2011), h.89-90 
Qur'an dan hadits. Orientasi ini adalah berupa keterampilan pasif, yaitu mendengar dan membaca, juga keterampilan aktif, yaitu berbicara dan menulis.

2. Tujuan Akademis

Yaitu belajar bahasa Arab untuk tujuan akademis guna memahami ilmuilmu yang ditulis menggunakan bahasa arab. Atau, guna memahami dan menguasai keterampilan berbahasa (istima',kalam, qira'ah dan kitabah). Orientasi dan tujuan ini lebih mengarah pada penempatan bahasa Arab sebagai disiplin ilmu yang dijadikan mata pelajaran atau mata kuliah yang harus dikuasai. Hal seperti ini biasanya identik pada studi bahasa Arab yang terdapat dilembagalembaga pendidikan, seperti pendidikan bahasa Arab, sastra Arab, program pascasarjana dan lembaga ilmiah lainnya.

3. Tujuan Profesionalisme atau Praktis

Yang dimaksud disini adalah belajar bahasa Arab untuk tujuan profesi, praktis dan pragmatis, yaitu untuk bisa berbicara dan berkomunikasi dengan bahasa Arab. Biasanya, tujuan seperti ini ditempuh oleh orang-orang yang ingin menjadi TKI diwilayah Timur Tengah, diplomat, turis, berdagang atau untuk melanjutkan studi ke wilayah Timur Tengah.

4. Tujuan Ideologis dan Ekonomis

Yaitu mempelajari bahasa Arab dengan tujuan untuk memahami dan menggunakan bahasa Arab sebagai media dan alat untuk kepentingan orientalisme, kapitalisme, imperialisme dan lain-lain. Hal semacam ini ditandai dengan banyaknya lembaga khusus mempelajari bahasa Arab didunia Barat.

Dari beberapa orientasi dan tujuan yang telah dipaparkan diatas maka proses pembelajaran bahasa Arab pada hakikatnya dapat dismpulkan paling tidak menjadi dua macam tujuan utama yaitu pembelajaran bahasa Arab:

1. Sebagai alat bantu bagi peningkatan keahlian lain yang harus dipelajari.

2. Sebagai tujuan yakni bertujuan untuk menghasilkan ahli bahasa dan sastra Arab agar mampu mengajarkan bahasa Arab itu sendiri dan menguasai dan mampu mengajarkan bahasa Arab

\section{Tujuan Pembelajaran Bahasa Arab Secara Khusus}

Tujuan khusus ialah tujuan yang ingin dicapai dari mata pelajaran atau mata kuliah saat itu yang biasa disebut dengan tujuan jangka pendek. Tujuan ini harus dicantumkan dalam buku persiapan. Tujuan khusus merupakan penjabaran dari tujuan umum. Misalnya, tujuan umum pelajaran muthalaah ialah keahlian dalam mengucapkan/ melahirkan gagasan, dan kemampuan mengucapkannya dengan lafal yang benar, serta kecepatan memahami, memikirkan isi yang dibaca dan menanamkan kemampuan mengingat kembali 
(reproduction). Sedangkan tujuan khususnya ialah kefasihan menyebutkan masingmasing huruf menurut makhrajnya seperti $d z a$, tsa, jim dan seterusnya.

Tujuan khusus berarti adalah setiap tujuan yang ingin dicapai setelah pembelajaran berlangsung dengan memperhatikan usia pembelajar, kebutuhan pembelajar serta jenjang pendidikan pembelajar.

Dewasa ini, pembelajaran bahasa Arab di Indonesia sudah mulai tersebar keperguruan tinggi Islam. Hal ini tampak dengan adanya jurusan pendidikan bahasa Arab yang dibuka di UIN, IAIN, dan STAIN. Bahkan, hal tersebut juga sudah menjalar ke perguruan tinggi swasta STAI, UNMUH dan lain-lain. Akan tetapi, yang disayangkan adalah sumber daya manusia sebagai pengajar dan sumber referensi sebagi rujukan masih sangat kurang bahkan bisa dikatakan miskin.

Tidak hanya miskin sumber daya manusia dan referensi, tampaknya semakin tragis lagi dengan adanya kurikulum pembelajaran bahasa Arab yang ada di Indonesia bersifat ijtihadi dari masing-masing lembaga bukan merupakan hasil ketetapan dari Kementrian Agama RI. Dalam setiap kurikulum yang bersifat ijtihad institusiaonal ini pun terjadi kesimpang siuran antara dua tujuan utama dalam pembelajaran bahasa Arab yaitu:

1. Pembelajaran bahasa Arab sebagai tujuan, dimaksudkan untuk membina ahli bahasa Arab, yang meliputi bidang ilmu bahasa (linguistik), bidang pembelajaran bahasa dan bidang sastra.

2. Pembelajaran bahasa Arab sebagai alat, dimaksudkan untuk memberikan kepada siswa kemahiran dalam bahasa Arab dalam aspek tertentu sebagai alat untuk keperluan tertentu pula. Misalnya, sebagai alat untuk komunikasi dalam pergaulan sehari-hari, sebagai alat untuk memahami buku-buku berbahasa Arab, sebagai alat pembantu keahlian lain (supplementary), sebagai alat pembantu tehnik (vocational).

Berdasarkan prosesnya, pembelajaran bahasa Arab sebagai alat harus dibedakan secara jelas dengan pembelajaran bahasa sebagai tujuan. Berdasarkan analisis kebutuhan mahasiswa dalam belajar bahasa Arab memunculkan beberapa kelompok sesuai kebutuhan, yaitu:

a) Kelompok jurusan bahasa Arab dan Keagamaan, meliputi jurusan Bahasa dan Sastra Arab, jurusan Pendidikan Bahasa Arab.

b) Kelompok ICP (International Clasroom Program), meliputi jurusan Pendidikan Agama Islam, Jurusan Pendidikan IPS, jurusan Syari'ah., jurusan Pendidikan Guru Madrasah Ibtidaiyah.

Karena itu pembelajaran di perguruan tinggi harus difokuskan pada salah satu dari dua klasifikasi di atas. Pengklasifikasian tersebut perlu dilakukan untuk menentukan kurikulum pembelajaran. Apakah mengambil kelompok 
yang pertama, kedua, atau mengklasifikasikan mahasiswa menjadi dua sesuai background jurusan pendidikan, jurusan dan kebutuhannya. Karena itu placement test tidak hanya didasarkan pada tingkat kemampuan saja, tetapi juga berdasarkan jurusan dan kebutuhannya.

Studi bahasa Arab dilembaga pendidikan kita mengalami disorientasi: tidak jelas arah dan tujuannya ${ }^{28}$. Hal ini, antara lain, terlihat pada sruktur program kurikilum PBA yang bermuatan beberapa mata kuliah yang tampaknya tidak semuanya revelan dengan visi dan misi PBA. Mata kuliah seperti: nushush adabiyyah dan 'ilm al-'arudh (metrics) agaknya sudah tidak revelan dengan keburuhan riil mahasiswa maupun kebutuhan pasar. Selain antara itu, antara satu mata kuliah dengan lainnya terkesan kurang saling melengkapi dan memperkuat basis dan kerangka keilmuan. Sebagai contoh kasus, ketika membelajarkan insya (composition), penulis banyak disibukan dengan urusan pembenahan dan pembekalan kaedah-kaedah nahwu dan sharaf, disamping penguatan pola berpikir logis. Hal ini menunjukkan bahwa pembelajaran nahwu dan sharaf belum mampu menuntaskan persoalan-persoalan yang seharusnya dipecahkan dalam perkuliahan itu. Pada saat yang sama, fakta ini juga menunjukan bahwa para mahasiswa belum banyak menerima latihan (tadribat nahwiyyah atau sharfiyyah) yang jika dikembangkan semestinya membuat mereka terlatih menyusun kalimat baku secara baik dan benar. Dalam struktur program kelompok ICP (International Class Room) yang meliputi jurusan Pendidikan Agama Islam, Jurusan Pendidikan IPS, jurusan Syari'ah yang mengusung tujuan dan orientasi pembelajaran bahasa Arab adalah sebagai alat untuk memahami dan meningkatkan keahlian lain seperti mampu membaca dan memahami literatur-literatur yang berbahasa Arab29, tampak beberapa mata kuliah yang tampaknya tidak revelan dengan tujuan pembelajaran, seperti mata kuliah bahasa Arab namun yang diajarkan bukan kemahiran membaca tetapi diprioritaskan pada pembelajaran nahwu dan shorof, seharusnya sisi garamatika bukan dijadikan fokus utama pembelajaran akan tetapi kemahiran membaca dan fahmul maqru'nya yang lebih ditekankan.

Orientasi studi bahasa Arab pada pendidikan tinggidi Indonesia tampak masih mendua dan setengah-setengah: antara orientasi kemahiran, dan orientasi keilmuan. Keduanya memang perlu dikuasai oleh mahasiswa, namun salah satu dari keduanya perlu dijadikan sebagai fokus: apakah bahasa Arab diposisikan sebagai studi keterampilan yang berorientasi kepada pemahiran mahasiswa dalam empat keterampilan bahasa secara mumpuni? Ataukah bahasa Arab

28 Acep Hermawan, Metodologi Pembelajaran Babasa Arab, (Bandung: Remaja Rosdakarya, 2011), h.94

${ }^{29}$ Muhammad Izzan, Metodologi Pembelajaran Bahasa Arab, (Bandung: HUMANIORA, 2009), h. 75 
diposisikan sebagai disiplin ilmu yang berorientasi kepada penguasaan tidak hanya kerangka epitemologinya, melainkan juga subtansi dan metodologinya.

Jika orientasi pertama yang dipilih, maka idealnya 70\% mata kuliah di PBA bermuara pada pengembangan: mendengar, berbicara, membaca, menulis dan menerjemahkan. Sisanya, 30\% untuk pengayaan materi keilmuan bahasa Arab, kefakultasan dan MKU (Mata Kuliah Umum/universitas). Sebaliknya jika orientasi kedua yang dipilih, maka idealnya 70\% mata kuliah di PBA bernuansa: 'ilm al-ashwat (fonologi), 'ilm al-sharf (morfologi), 'ilm al-nahwi (sintaksis), 'ilm al-dilalah (semantik), 'ilm al-mu'jam (leksikografi), metodologi penelitian bahasa Arab, linguistik terapan ('ilm al-lughah al-tathbiqi), sosiolinguistik ('ilm allughah al-ijtima'i), psikolinguistik ('ilm al-lughah al-nafsi), linguistik teks ('ilm lughat al-nashash), sejarah dan filsafat bahasa Arab, dan sebagainya.

Selain itu, kebijakan pendidikan dan pembelajaran bahasa Arab di lembaga pendidikan lainnya, selama ini, juga tidak menentu. Ketidak menentuan ini dapat dilihat dari beberapa segi30. Pertama, dari tujuan, terdapat kerancuan antara mempelajari bahasa Arab sebagai tujuan atau sebagai alat untuk menguasai pengetahuan yang lain yang menggunakan bahasa Arab (seperti mempelajari tafsir, fiqh, hadits, dan sebagainya). Kedua, dari segi bahasa Arab yang dipelajari, apakah bahasa Arab klasik (fushha turats), bahasa Arab modern/kotemporer (fushha mu'ashirah) atau bahasa Arab pasaran ('amiyyah). Ketiga, dari segi metode, tampaknya ada kegamangan antara mengikuti perkembangan dan mempertahankan metode lama. Dalam hal ini, bahasa Arab banyak diajarkan dengan menggunakan metode qawa'id wa tarjamah.

Tantangan lainnya yang juga tidak kalah pentingnya dalam pengembangan pendidikan bahasa Arab adalah rendahnya minat dan motivasi belajar serta kecendrungan sebagai mahasiswa bahasa Arab untuk "mengambil jalan yang instan" tanpa menulis proses ketekunan dan kesungguhan. Hal ini terlihat dari karya-karya dalam bentuk makalah dan skripsi yang agaknya cenderung merosot atau kurang berbobot mutunya. Mahasiswa yang sudah berada di "dunia PBA" bahasa Arab seakan tidakk betah dan ingin mencari "dunia lain", sehingga ini perlu disurvei dan dibuktikan secara akademis tidak sedikit yang mengeluh bahwa jurusan bahasa Arab itu sebetulnya bukan "habitat" mereka yang sesungguhnya.

Sumber-sumber dan literatur kebahasaaraban di pendidikan tinggi juga masih relatif kurang, jika tidak dikatakan terbatas. Hal ini, antara lain, disebabkan oleh minimnya perhatian pimpinan fakultas dan universitas untuk

\footnotetext{
${ }^{30}$ Acep Hermawan, Metodologi Pembelajaran Bahasa Arab, (Bandung: Remaja Rosdakarya,2011), h.94-95
} 
mengembangkan pendidikan bahasa Arab; dan juga disebabkan oleh kurangnya hubungan lintas-universitas atau lembaga pendidikan dalam bentuk kerjasama ilmiah kita dengan perguruan tinggi di Timur Tengah, sehingga kita tidak banyak mendapat pasokan sumber-sumber dan hasil-hasil penelitian kebahasaaraban. Selain itu, penting juga ditegaskan bahwa perhatian negaranegara Arab dalam bentuk penyediaan sumber belajar, termasuk referensi dan literatur yang memadai, untuk negara berkembang seperti Indonesia, relatif masih kurang, jika dibanding dengan negara-negara Barat, seperti Amerika dengan Amcor (American Cornernya)-nya.

\section{Penutup}

Kurikulum adalah sebuah rangkaian program yang disusun dan dilaksanakan untuk mencapai suatu tujuan pendidikan, adapun kurikulum pendidikan tinggi untuk pembelajaran bahasa arab adalah suatu rangkaian program yang dimaksudkan untuk mencapai tujuan untuk menjadikan mahasiswa mampu dan cakap dalam bidang bahasa arab, terlepas tujuan pembelajaran bahasa arab sebagai tujuan atau sebagai alat.

Berdasarkan prosesnya, pembelajaran bahasa Arab sebagai alat harus dibedakan secara jelas dengan pembelajaran bahasa sebagai tujuan, dan hal ini harus bisa terlihat dalam kurikulum pembelajaran tersebut sebagai tujuan instruksional.

Pembelajaran Bahasa Arab sebagai alat terlihat dari sejauh mana bahasa arab dipelajari dalam prosesnya apakah sebagai penguat dari tujuan kurikulum atau alat untuk mencapai tujuan kurikulum itu sendiri. Sedangkan Pembelajaran sebagai tujuan adalah dimana Bahasa Arab dipelajari sebagai tujuan kurikulum itu sendiri atau dalam arti lain Bahasa Arab dipalajari secara menyeluruh baik itu keilmuan atau keterampilannya sebagai satu kesatuan yang harus dimiliki oleh pembelajar tersebut.

\section{Daftar Pustaka}

A. Akrom Malibary dkk, Pedoman Pembelajaran Bahasa Arab Pada Perguruan Tinggi Agama/ I.A.I.N, Jakarta: Depag R.I, 1976.

Abu Bakar Muhammad, Metode Kbusus Pembelajaran Bahasa Arab, Surabaya: Usaha Nasional, 1981

Acep Hermawan, Metodologi Pembelajaran Bahasa Arab, Bandung: Remaja Rosdakarya, 2011

Akhmad Muzakki, Stilistika al-Qur'an; Gaya Babasa al-Qur'an dalam Konteks Komunikasi, Malang: UIN Press,2009 
Departemen Pendidikan dan Kebudayaan, Kamus Besar Babasa Indonesia, Jakarta: Balai Pustaka,1989.

Depdiknas, Buku Pedoman Kerangka Kualifikasi Nasional Indonesia, Jakarta: direktorat Jenderal Perguruan Tinggi, 2010.

Direktorat Akademik Direktorat Pendidikan Tinggi, Buku Panduan Pengembangan Kurikulum Berbasis Kompetensi Pendidikan Tinggi (Sebuah Alternatif Penyusunan Kurikulum), Jakarta, 2008

Fadhil Fathy Muhammad Waly. 1998.Tadris al-Lughah al-Arabiyyah Fy al-Marbalah al-Ibtida'iyyah: Thuruqubu, Asalibubu, Qadhayabu. Ha'il: Dar al-Andalus Li al-Nasyr wa al-Tauzi', 1998

Henry Guntur Tarigan, Pembelajaran Kompetensi Bahasa. Bandung: Angkasa, tt

Ibrahim Anis dkk, Al-Mu'jam al-Wasith, tk: tp, tt.

Kemendiknas RI. Nomor 045/U/2002, tentang Kurikulum Inti Pendidikan, Pendidikan Tinggi.

Kemendiknas RI. Nomor 232/U/2002 tentang Pedoman Penyusunan Kurikulum Pendidikan Tinggi dan Penelitian Hasil Belajar Mahasiswa

Leo Agung. 2010. Tinjauan Kurikulum Pendidikan Sejarah Program Pasca Sarjana UNS. Majalah ilmiah IPS. Vol.11.No. 2 September 2010

Muhammad Izzan, Metodologi Pembelajaran Bahasa Arab, Bandung: Humaniora, 2009.

Musthafa Al-Ghalayaini, Jami' ad-Durus al-Arabiyabjilid 1,Beirut: Dar al-Kutub alIslamyah, 2005.

Patricia L. Smith dan Ragan T.L, Instructional Design. Upper Saddle River, New York: Merril Prentice Hall Inc; 2003.

Robert M. Gagne, Principle Of Instructional Design, New York: Wadsworth Publishing Co, 2005.

Sutrisno dan suyadi, Desain kurikulum Perguruan Tinggi mengacu KKNI, Bandung: Remaja Rosdakarya, 2016.

Tresno Dermawan Kunaefi, dkk. Buku Panduan Pengembangan Kurikulum Berbasis Kompetensi Pendidikan Tinggi, Jakarta: Dirjen Pendidikan Tinggi, 2008

Umi Machmudah dan Abdul Wahab Rosyidi, Active Learning dalam Pembalajaran Babasa Arab, Malang: UIN Press, 2008

Undang-Undang No. 14 tahun 2005. Tentang Guru dan Dosen.

Walter Dick dkk, The Systematic Design Of Instruction, New York: Pearson, 2005.

Y. Miarso, Menyemai Benih Teknologi Pendidikan, Jakarta: Penerbit Kencana, 2005. 